\title{
Studies on the Catch Composition of Palair Reservoir
}

\author{
T. Suguna* \\ Fisheries Research Station, S.V. Veterinary University, West Godavari, \\ Andhra Pradesh, India \\ *Corresponding author
}

\section{A B S T R A C T}

\section{Keywords \\ Palair Reservoir, Catch, Composition, Morphotypes, Production potentiality, Evaluation of judicious exploitation}

Article Info

Accepted:

12 October 2020 Available Online: 10 November 2020

\begin{abstract}
Reservoirs are the "Sleeping giants of Indian Fisheries". The Palair reservoir is a tributary of river Krishna located at Palair village of Kusumanchi mandal, Khammam district, Telangana state, India. It is balancing reservoir of Nagarjuna Sagar left canal. Besides being the source of irrigation, electricity generation, it is also surviving as sole source of aquaculture activity providing nutritional security, employment and livelihood to fishermen cooperative societies of Khammam and Nalgonda districts. Its aquaculture production is representing the whole Telangana region. A study was undertaken to collect baseline data on the ecological features and fish and fisheries. The data on fish community, plankton and physiological parameters were recorded at fortnightly intervals. The fish fauna was comprised of major carps, exotic carps, minor carps, cat fishes, freshwater prawns and large populations of trash fishes. This study on Palair reservoir gained knowledge on its production potentiality, Icthyofauna and shell fisheries. This will stimulate and initiate action towards conservation of threatened fish resources, judicious exploitation of economically important species and also for further enhancing the ranching of seed in Palair Reservoir and upgrade socio-economic status of fishermen community.
\end{abstract}

\section{Introduction}

Reservoirs are often referred to as "sleeping giants of Indian Fisheries. Reservoir or manmade lakes, are created primarily for irrigation, power generation and other water resource development process. These water bodies have become the prime inland fisheries resource of India due to many reasons: development of reservoir fisheries also brings with it many economic and social advantages, they form an important source for increasing fish and prawn production. Along with irrigation, the reservoir fisheries play a significant role in providing the livelihood opportunities to many rural fishers. Although India has vast freshwater resources, they are not fully exploited except in a limited scale for carp culture. These are the main opportunities for improving the livelihood and nutritional security through aquaculture. Five reservoirs are located in the district Khammam, Telangana, out of which three are larger and the rest two are smaller. Kinnerasani reservoir is a crocodile sanctuary. Wyra and Palair reservoirs serve for Irrigation and Aqua production. 
Freshwater prawn culture and fish culture technology have become popular for use in large number of tanks and ponds. However, most reservoirs are underutilized for this purpose in the country.

Palair reservoir, a tributory of river Krishna, is a breath taking, beautiful reservoir located in village of Palair Kusmanchi mandal of Khammam district of Telangana. It is about $30 \mathrm{~km}$ away from district head quarters of Khammam, $2 \mathrm{~km}$ from Palair village and is on Suryapet - Khammam road. It is the balancing reservoir of Nagarjuna Sagar left canal, with water spreading over an area of 1748 ha and with a storage capacity of 2.5 TMC of water. The water here is free of pollution and offers a best place for water based adventure and entertainment. For peace seekers, this place offers a best spot to relax with its serene backdrop and an adventurous boating facility, this place provides good water sports and activities (Fig. 1).

Apart from feeding the ayacut under the Nagarjunasgar left canal system, this reservoir is the main drinking water source for nearby villages. It is also water storage facility for a large number of villages and towns nearby Khammam. The water from this reservoir is diverted to nearly 17 canals, which includes Bonakal branch canal and Mangapuram branch canal for irrigation.
This reservoir is also serving as a sole source of livelihood for over 14,500 members enrolled in as many as 184 fishermen cooperative societies in district. Palair reservoir is $28-30 \mathrm{~km}$ from head quarter of Khammam. The purpose of this reservoir is irrigation, aquaculture activity, employment and electricity generation. Locationally it is $17^{\circ}-12^{\prime}-12^{\prime} \mathrm{N}$ latitude and $79^{\circ}-54^{\prime}-10^{\prime} \mathrm{E}$ longitude. Ijhhght's water basin is river Krishna with a maximum water level of +444.310 mts. and Maximum dam highest of $20.57 \mathrm{mts}$. The full Reservoir level is +439.310 meters with catchment area of 651.24 sq.mts. The average rainfall is 790 $\mathrm{mm}$.

The Palair reservoir is a balancing reservoir and is a major hub of freshwater fish and prawn culture. Its abundant water resources, earn a niche for itself in freshwater fish and prawn production, in the entire region. The freshwater fish and prawn are "must-eat" here as good quality / fresh variety of them are readily available. The freshness of the lake water makes it a good place for rearing fish and prawn thus enhancing the economical growth. According to sources, the production of freshwater fish and prawn production is estimated to be over 18,000 MT and $600 \mathrm{MT}$ respectively.

\section{Morphological features of Palair Reservoir}

\begin{tabular}{|l|l|l|l|}
\hline 1. & Village & - & Palair \\
\hline 2. & Mandal & - & Kusmanchi \\
\hline 3. & Distance from km & - & $23 \mathrm{~km}$ \\
\hline 4. & Purpose of reservoir & - & Irrigation, fish culture, electricity, generative \\
\hline 5. & Latitudes & - & $17^{\circ}-12^{\prime}-12^{\prime} \mathrm{N}$ \\
\hline 6. & Longitudes & - & $79^{\circ}-54^{\prime}-10^{\prime} \mathrm{E}$ \\
\hline 7. & Water basin & - & Krishna \\
\hline 8. & Full reservoir level & - & $+439.310 \mathrm{mts}$ \\
\hline 9. & Maximum water level & - & $+444.310 \mathrm{mts}$ \\
\hline 10. & Maximum height of Dam & - & $20.57 \mathrm{mts}$. \\
\hline 11. & Catchment area & - & $651.24 \mathrm{sq} \cdot \mathrm{mts}$ \\
\hline 12. & Average rain fall & - & $790 \mathrm{~mm}$. \\
\hline
\end{tabular}




\section{Materials and Methods}

Culture trails of fin fish and shell fish have been carried out successfully in Palair reservoir of Khammam district. The concerned fishermen community of reservoirs regularly stock wild freshwater prawn juveniles and early fingerlings of fish from the Godavari River in Andhra Pradesh every year in the months of July to August. The fish and prawns are harvested during April - June. Study carried out from August 2018 - May 2019.

Monthly samplings were done regularly to identify the species in the catch composition and morphotypes.

The variety of species and their abundance were recorded fortnightly.

The hydrobiological, physico chemical parameters were recorded fortnightly.

The seasonal variance of qualitative and quantitative analysis of plankton are assessed.

\section{Results and Discussion}

The members of fisherman cooperative societies of both Khammam and Nalgonda districts, embark on fishing in Palair Reservoir.

They initiate their fishing activity usually in the month of April / May as per the permission of officials, state department of fisheries (1a, 1b, 1c, 1d, 1e and 1f).

The average yield obtained was recorded as 300 tonnes of fish and 70 tonnes of prawns. The catch composition of fish fauna (Fig. 6), seasonal qualitative and quantitative variance of plankton (Fig. 7), water quality parameters (Table 1) and various morphotypes in freshwater prawn (Fig. 3,4,5,) and quality production potentiality of Palair Reservoir, Telangana (Fig. 8) are recorded as below.

Regarding the fin fisheries of the catch composition, the present investigation revealed rich assemblage of both naturally occurring and stocked fish species, indicating that the Palair Reservoir harbour a rich and variety of Fish fauna.

The fish composition mainly included major carps, cat fishes, minor carps and the large quantum of trash fish, taxonomically about 60 sps belonging to 40 families were found which mainly include Clupodae, Notopteridae, Cyprinidae, Siluridae, Channaidae and Bagride. The major indentified fish species from the fish fauna included Labeo rohita, Catla catla, L.calbasu, L.gonius, Punticus sps. Cirrhinus mrigala, $C$. reba, Mystus tengara, M. seenghala, Nandus nandus, Gudusia chapra, Notopterus notopterus, Wallago attu, Mastacembus arnatuse etc. The detailed list of fish composition from the reservoir is tabulated in Table 2, 3 .

In catch composition the percentage of $M$. malcolmsonii is found to be $80 \%$ whereas $M$. rosebergii is $20 \%$ (Fig. 1e, 2, 3 and 4). The morphotypes like runt, orange clawed and blue clawed in males and in female immature, mature, gravid, spent are observed in $M$. rosenbergii (Fig. 4 and 5). The monthly growth performance of freshwater prawn is very encouraging with a mean weight of 60 gm. The blue green algae, green algae and diatoms are noticed under phytoplankton whereas protozoa, rotifers, copepods and cladocerans are observed under zooplankton. Quantitatively phytoplankton is high in rainy season whereas zooplankton in winter season (Fig. 6). During the study all the water quality parameters are noticed to be in favourable range (Table 1) (Fig. 7, 8, 9, 10, 11, 12, 13, 14, 15 and 16). 
The physical, chemical and hydro-biological water quality parameters of Palair reservoir are very optimum for the survival and growth of aquatic animals (fish and prawn). Qualitatively and quantitatively it is rich in plankton production. The ichthyofauna harbour on an average 60 species of fishes, of which at least 40 contribute to the commercial fisheries (Roy et al., 2015 and Valarmathi, 2017). Though the Indian major carps occupy a prominent place among the commercial important species, more recently exotic species, murrels and freshwater prawns sps. also contribute substantiously to commercial species.

Table.1 Range of water quality parameters in Palair reservoir

\begin{tabular}{|c|c|c|c|c|c|c|}
\hline $\begin{array}{c}\text { Month of } \\
\text { samplings }\end{array}$ & \multicolumn{2}{|c|}{ Temperature } & pH & D.O. (mg / & Depth (It) & $\begin{array}{c}\text { Alkalinity } \\
\text { (mg/lt) }\end{array}$ \\
\hline July - May & 27.50 & Water & & & & \\
\hline
\end{tabular}

Table.2 Ichthyofauna of Palair reservoir

\begin{tabular}{|c|c|c|c|}
\hline S.No. & Families & Species & Abundance \\
\hline 1. & Clupideae & Guduria chapra & $\mathrm{A}$ \\
\hline 2. & Notopteridae & Notopterus notopterus & A \\
\hline \multirow[t]{12}{*}{3.} & \multirow[t]{12}{*}{ Cyprimidae } & Cyprinus carpio & $\mathrm{L}$ \\
\hline & & Tor tor (Masheer) & $\mathrm{S}$ \\
\hline & & Puntius sophora & $\mathrm{L}$ \\
\hline & & P. sarana & M \\
\hline & & Cirrhinus mrigala & M \\
\hline & & C. reba & M \\
\hline & & Labeo gonius & A \\
\hline & & L. bata & $\mathrm{L}$ \\
\hline & & L. rohita & $\mathrm{L}$ \\
\hline & & L. calbasu & M \\
\hline & & Oxygaste rbacaila & $\mathrm{L}$ \\
\hline & & Catla catla & $\mathrm{L}$ \\
\hline \multirow[t]{4}{*}{4.} & \multirow[t]{4}{*}{ Bagridae } & Mystus seenghala & $\mathrm{L}$ \\
\hline & & M. cavasius & S \\
\hline & & M. oar & $S$ \\
\hline & & M. tengara & M \\
\hline 5. & Heteropneustidae & Heteropneustus fossils & $\mathrm{L}$ \\
\hline \multirow[t]{2}{*}{6.} & \multirow[t]{2}{*}{ Siluridae } & Ompak oebda & M \\
\hline & & Wallago attu & $\mathrm{S}$ \\
\hline 7. & Charidae & Clarias batrachus & $\mathrm{L}$ \\
\hline \multirow[t]{4}{*}{8.} & \multirow[t]{4}{*}{ Channidae } & Channa gachua & M \\
\hline & & C.marutius & A \\
\hline & & C. punctatus & A \\
\hline & & C. striatus & A \\
\hline 9. & Anabantidue & Colisa gfasciatus & $\mathrm{S}$ \\
\hline \multirow[t]{2}{*}{10.} & \multirow[t]{2}{*}{ Mastacembelidae } & Mastacembelus armatus & M \\
\hline & & M. acculeatus & $\mathrm{L}$ \\
\hline
\end{tabular}

A: Most abundant; M: Moderately abundant; L: Less abundant; $\quad$ S: Seasonally 
Table.3 Status of exotic fin fisheries in Palair reservoir

\begin{tabular}{|c|c|c|c|}
\hline S. No. & Common name & Scientific name & Status \\
\hline 1. & Common carp & Cyprinus carpio & Limited \\
\hline 2. & Grass carp & Ctenopharyn godon idella & Limited \\
\hline 3. & African catfish & Clarius gariepinus & Limited \\
\hline 4. & Pangus & Pangasianodon hypophthalmus & Rare \\
\hline 5. & Red bellied pacu & Piaractus brachiopomus & Rare \\
\hline 6. & Nile tilapia & Oreochromis niloticus & Abundant \\
\hline 7. & $\begin{array}{l}\text { Mosombique } \\
\text { tilapia }\end{array}$ & Oreochromis niloticus & Abundant \\
\hline 8. & Mosquite fish & Gambusia affnis & Common \\
\hline 9. & Guppy & Lebistes reticulates & Limited \\
\hline 10. & Giant gouramy & Osphronemus goray & Rare \\
\hline 11. & Sail fin catfish & Pterygoplichthys pardalis & Limited \\
\hline
\end{tabular}

Fig.1a Palair reservoir Fig.1b Stocking of seed

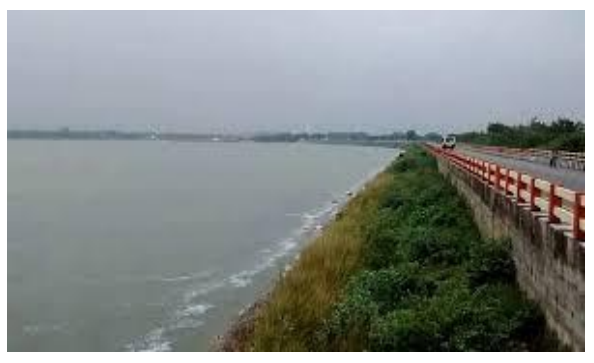

Fig. 1c Harvesting
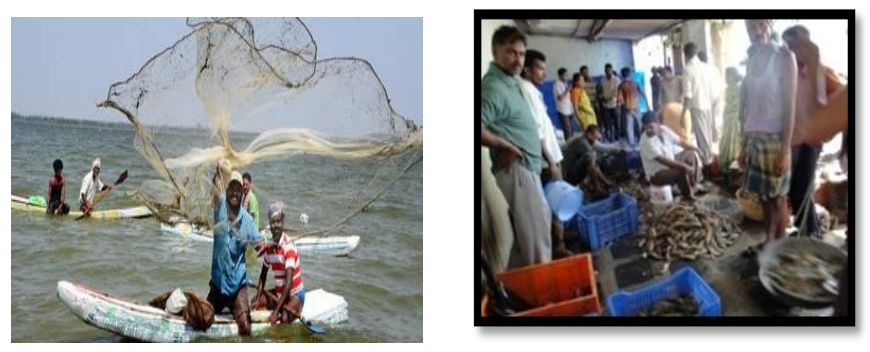

Fig.1e Haul of shell fish (M.malcolmsonii)

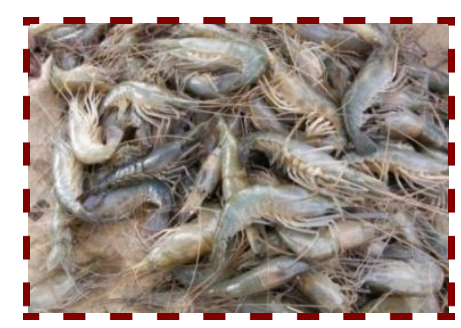


Fig.2 Catch composition of freshwater prawn (shell fish)

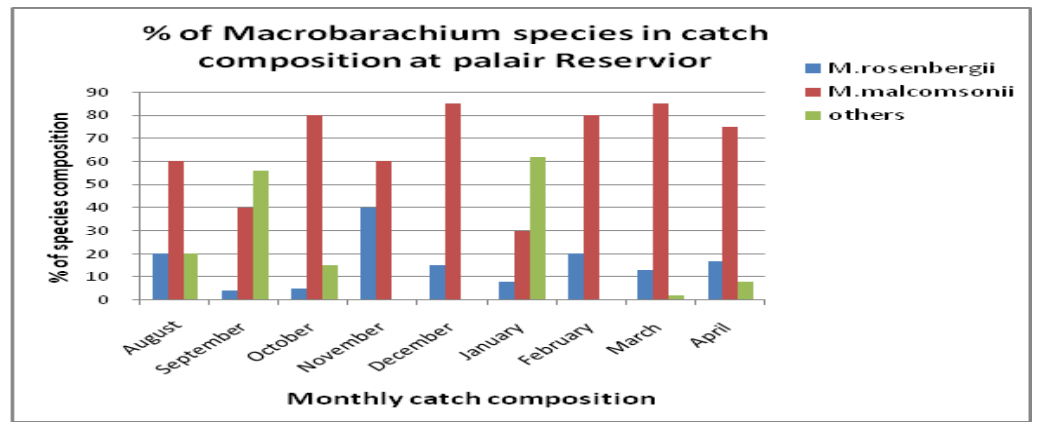

Fig.3 Morphotypes of M.malcolmsonii Fig. 4 M.rosenbergii Fig. 5 Morphotypes of M.rosenbergii

Morphotypes in catch composition of shell fish (prawn)

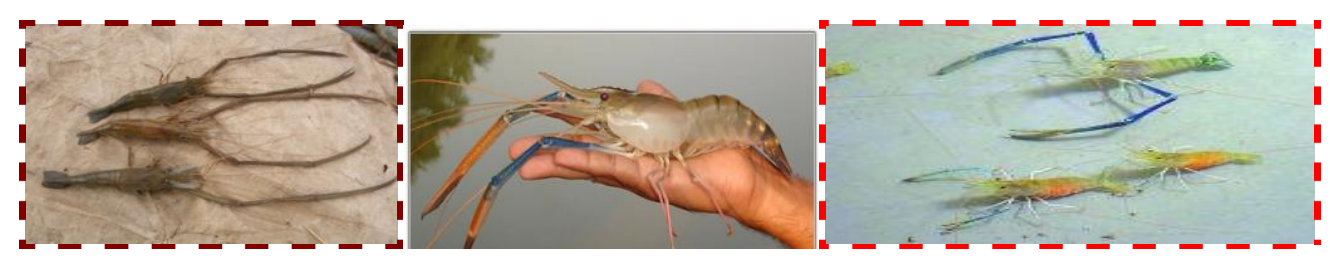

Fig. 3 Morphotypes of M.malcolmsonii

Fig. 4 M.rosenbergii

Fig. 5 Morphotypes of M.rosenbergii

Fig.6 Seasonal variance of plankton

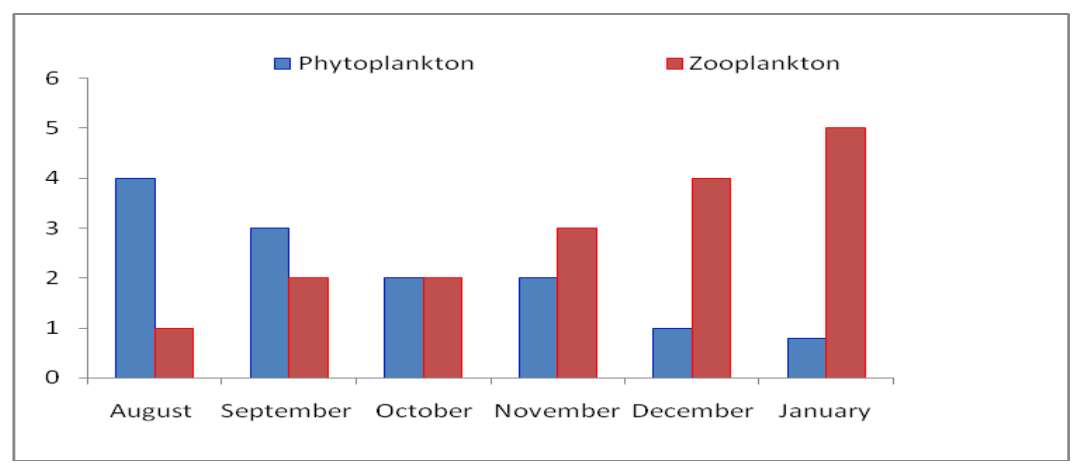

Fig.7 Haul of fish

Catch composition of fin fish

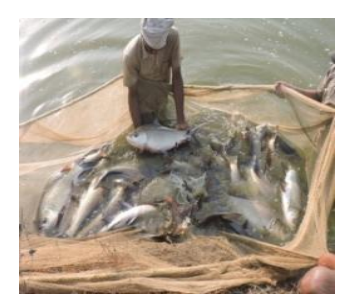



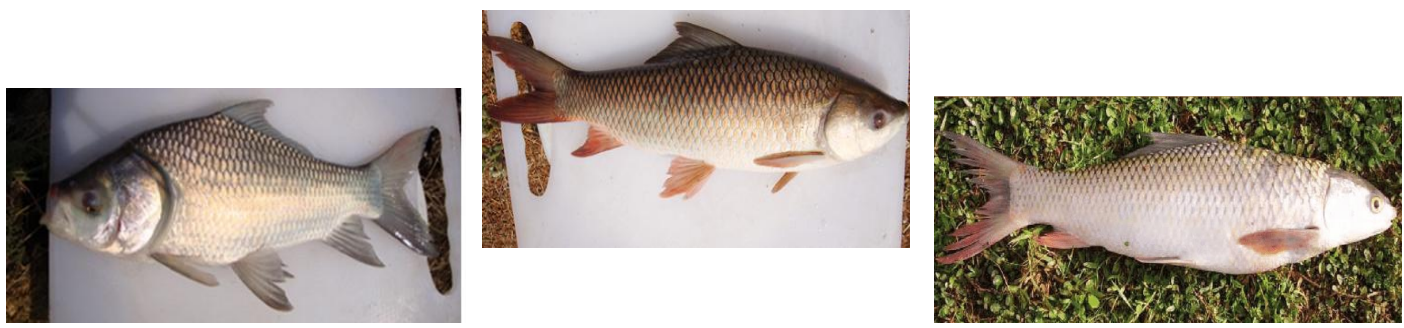

Fig.11 Wallago attu

Fig.12 P. hypophthalmus

Fig.13 Cyprinus carpio
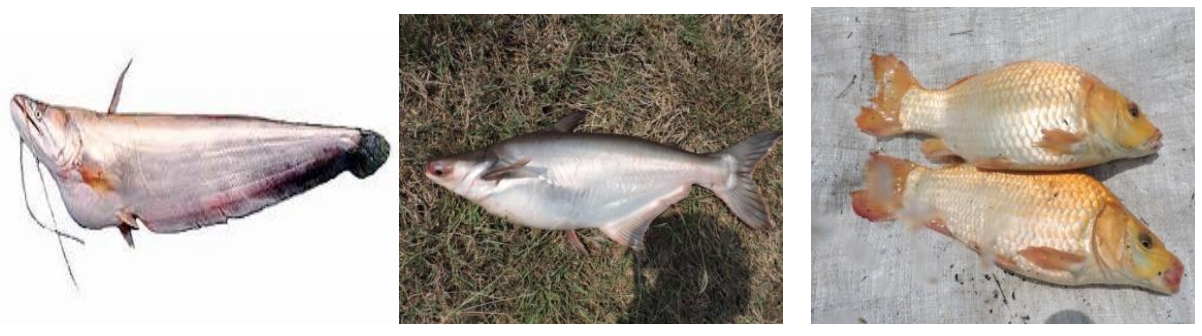

Fig.14 Grass carp

Fig.15 Channa striatus

Fig.16 Clarias batrachus
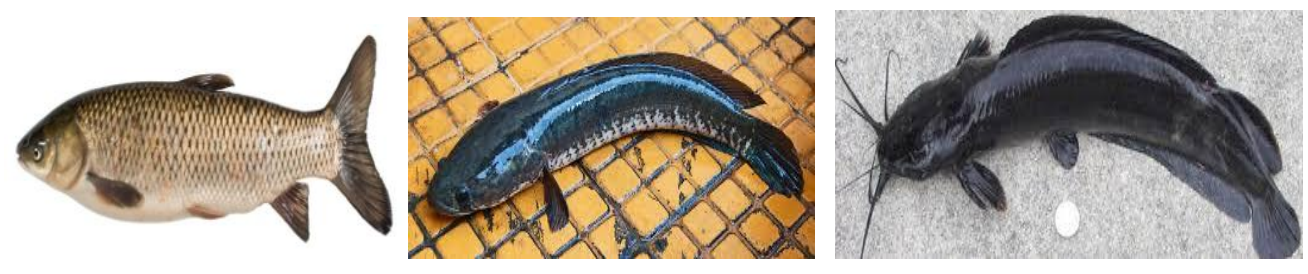

The total fish and prawn production from Palair reservoir is 60 metric / annum (2004$05)$ and the production of prawn touches 130 - 145 tonnes as against the $170-210$ tonnes of fish (2018-19). The aquaculture production of this reservoir is representing the whole Telangana aqua production.

In conclusion the palair reservoir is a parennial reservoir with no water scarcity. This favours the fishes to grow till the marketable size round the year with no impact of seasonal fluctuations of water level. Local demand for Palair reservoir fish (Indian major carps, exotic and air breathing) is very high for their unique taste. All these merit the
Palair reservoir for the development of culture based reservoir. This reservoir is arbitrarily stocked with fries and fingerlings of major carps of variable size and numbers. Hence it is essential to stock the reservoir with CIFRI recommended optimum size of $10 \mathrm{~cm}$ fingerlings (Selvaraj et al., 1995).

The global market for scampi is expanding with attractive prices and thus there is scope for an expansion of aqua production and export. About 4-5 million ha of impounded freshwater bodies in the various states of India, offer the potential for culture. The percentage of carnivorous fishes is very less in this reservoir aiding the reduced predation 
to stocked fishes. The data base on biotic and abiotic parameters, fish and fisheries fauna will assist for a meaningful management of the reservoir.

Still there are vast opportunities to increase productivity from the reservoirs. Timely and quality fish and prawn seed stocking is required to augment production levels. Moreover a sound marketing system will also fetch higher incomes which will further improve the socio-economic status of fishermen community.

Palair Reservoir is an additional source of income aside from the regular reservoir fishery in the state. The cooperative fishermen society of this area is the largest of all with 1500 society members. This reservoir is livelihood for eight villages (Thanda) around. To meet the demand, production from this underutilized reservoir is till wanting. By application of scientific management tools the judicious exploitation of economically important sps., conservation of threatened fish resources, production and productivity levels can be still enhanced and the socio-economic standards of the cooperative societies of the fishermen community can be upgraded.

\section{References}

Laxmappa, B. and Vijay Babu, B., 2014. Opportunities in Mahabubnagar district Andhra Pradesh for improving the livelihood of Fishers through Reservoir Fisheries, Fishing Chimes, 33 (12): 2628.

Laxmappa. B., Satya Parameswar, K. and Srinivas Reddy, B. 2013. Status of Freshwater prawn farming in Ramanpad reservoir in Mahabubnagar district of Andhra Pradesh., Fishing Chimes, 33(7): 29-31.

Roy, M.K.D., S. Rath and S. Mitra, 2015. Faunistic and Limnological studies on Palair lake, Wetland Ecosystem series 18. Published by zoological survey of India, 63-68 pp.

Selvaraj, C., V.K. Murugesan and V.K. Unnithan, 1995. Ecology Based Fisheries Management in Aliyar Reserini. Bull. Cent. Inland. Fish. Res. Inst., Barrackpore No. 72, 1997. 30 p.

Valarmathi, K. 2017 Crustacea: Decapods (Prawns and crabs), pp-313-331. In: Current status of freshwater faunal diversity in India. Published by zoological survey of India.

\section{How to cite this article:}

Suguna, T. 2020. Studies on the Catch Composition of Palair Reservoir. Int.J.Curr.Microbiol.App.Sci. 9(11): 1450-1457. doi: https://doi.org/10.20546/ijcmas.2020.911.171 